\title{
Music Deculturation: \\ A Traditional Thai Music Tool for Indonesian Music Adoption
}

\author{
Surasak Jamnongsarn \\ Srinakharinwirot University, Sukhumvit 23 Bangkok 10110 \\ temanbkk@hotmail.com \\ Lalita Poolsup \\ Suan Dusit University \\ lpoolsup@gmail.com
}

\begin{abstract}
There has been foreign music influence on traditional Thai music since Ayutthaya period. Pi Jawa (Java flute), Klong Jawa (Java drum) and some traditional Thai song with foreign title have been legally and literally evident in Ayutthaya era. Some said that Thai people are open-minded in music, harmonious mixing overseas music culture with their own. Ethnomusicologists have seen this social phenomenon via music context and explained the revolution of traditional Thai music differently from the acceptance of music in general. This article reviewed the acceptance of Indonesian music, including Javanese music from Central Java and Sundanese music from West Java, into the Javanese Idiomatic Melody in traditional Thai music and Angklung Thai style. Indonesian music was seriously and forcefully deculturated. Playing technique has been adjusted to suit Thai music playing. Tuning system of Javanese Gamelan in Thailand has been fine tuned to conform to that of Thai music. Physical appearance of Sundanese Angklung has been replaced with Angklung Thai style. Javanese song have undergone music elaboration and rewritten to satisfy Thai musicians, with approval from elite Thai musicians and previous Thai music institutes together with Thai people in the society.
\end{abstract}

Keywords: indonesian music, music deculturation, adoption

\section{INTRODUCTION}

Thailand and Indonesia, the latter being popularly known by the former as chawa (Java), are two nations with long relationship since the traditional state era. There are evidencesthat showed the multi-faceted acquaintance of Ayutthaya kingdom with Mataram territory whose center was located at Kartasura (pronounced karto-su-ro according to Javanese language) in the Java Island. This includedpurchase of horses from Java for Ayutthaya royal court uses (Dhiravat na Pombejra 2008, 65); establishment of diplomatic friendly relations by the King Phet Racha of Ayutthaya with the Javanese Mataram territory and exchange of state tributes and peppers with Jambi court, aterritory on Sumatra island under Kartasura's Mataram administration, in the reign of King Narai (Ricklefs 2001, 108). There was also traces of various cultural contacts, one of which was introduction of Inao, a Javanese literature, to Thailand on the late Ayutthaya kingdom. With two 
known variants: Inao yai (large or unabridged Inao) and Inao lek (small or abridged Inao), the novel would go on to become one of the most prominent Thai classical literatures and theatrical plays (R.M. Soedarsono 2011, 341). Inao was even used as a relationship bridge during a conversation between Thai and Javanese royal members when, in 1945, HM King Chulalongkorn visited the Dutch East Indies which is Indonesia today (His Majesty King Chulalongkorn 2555, 173).

\section{MUSICS OF INDONESIA (JAVANESE AND SUNDANESE) IN THAI MUSIC}

Evidences from Ayutthaya era shows various ways in which Thai music and Indonesian music are related. For an example, the word klong chawa, a membranophone known to have existed since the era, appeared in a royal title "Chalaad Klong Chawa" which was rhymed with "Chanai Pairoh". These titles, conferred as a part of phra aiyakarn tumnaeng naponlaruean natahaan huamuang, a law enforced by King Somdej Phra Boromma Tri Lokkanaat, denoted the court musicians whose duty was to beat klong chawa and blow pi chanai during a royal procession. Pi chawa is another instrument found to be used in processional music as the instrument was mentioned in Punnowaad kham chan to be the main instrument for the royal elephant procession's religious march towards phrapudthabaat (Buddha's Footprint).
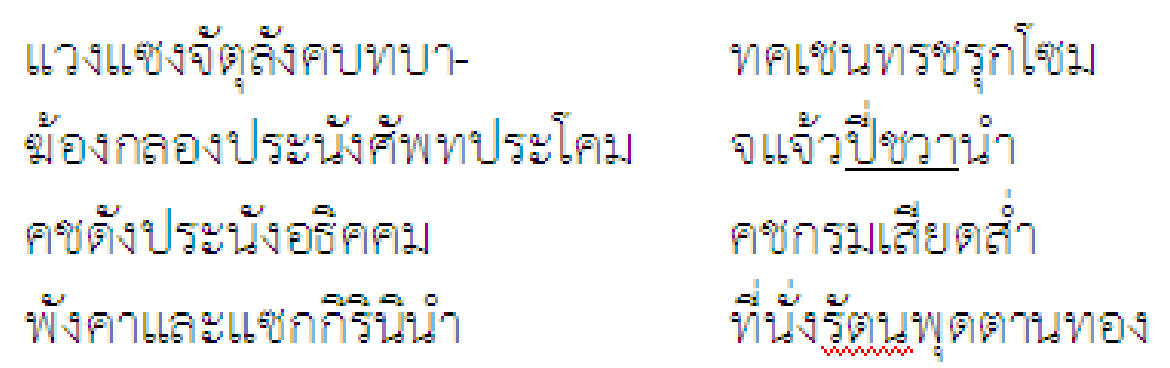

Punnowaad kham chan

Besides its use as processional music for Ayutthaya court, Javanese music was available to laymen as well. It was found that khongchawa appeared in the incantation of wai khru lakorn chatri and in pleng nhatrae, a piece that which honors teachers, in wai khru nora. These texts, still being used today, praise the quality of Javanese gongs that it has sonorous and tuneful timbre. With such high reputation given to the instrument, it is fair to assume that Java-made gongs were of such high quality that lakorn chatri and nora artists compared their voices to its sound while praying.

Repertory-wise, it has been found that several titles of Thai musical pieces may have had its original roots come from Melayu and Javanese language of Indonesia (Cherdchoo 2012,1). These pieces may be divided into two categories based on the time of composition: the old period and the new period. The former includes pieces like nirapatee whose title comes of Javanese narapati meaning a monarch or a mighty and is comparable to Thai naruebodi, yong-ngid from Javanese joget meaning dancing, khaek kulit (since the word kulit means leather or nung in Thai, 
the piece is also known alternatively as khaek nung), khaek awang, saraburong, and mulong. The pieces of the latter category were composed following the visits to Java by royal family in Rattnakosin (Bangkok) era. Some of them are preseban (from Javanese paseban), karad raya, Kediri, Semarang, yawa kao, yawa mai, yawa rew. Considering remnants of Javanese language in Thai musical instrument names and repertory titles, it is found that musical relationship between Thai and Indonesia has long existed in multiple points of time, has literature connection with the likes of Inao (Panji), Rammakien (Ramayana), and mahapharata (Mahabharata), and could as well extend to the field of dance (Duangchanthip, personal communication).

The image of Thai-Indonesia musical relationship became increasingly clear after a set of Sundanese angklung was brought to Thailand. Luang Praditpairoh (Sorn Silpabanleng), an important Thai music master who accompanied his master Prince Bhanurangsi Savangwongse - to Java in 1908, was the primary teacher for the instrument. Apart from angklung, repertory as well as characteristics peculiar to only Javanese music was also introduced by Luang Praditpairoh, for example, Bima kurda, a piece that became the model for yawa kao played on Thai angklung. Another type of Javanese instrument introduced to Thailand was Javanese gamelan which was given to HM King Prajadhipok by Sri Susuhunan Pakubuwana X, a ruler of Surakarta, during the former's visit to Java in 1929. The court of Surakarta even composed a new piece on gamelan to honor the presence of the Thai king.

There is an interesting anecdote, recorded in an archive, on the giving of this particular set of gamelan that King Prajadhipok officially received the instruments while he was in Surakarta on September 1929 before he returned to Thailand on October in the same year. Two months later, the King made an inquiry why the gamelan had not arrived at Bangkok. Having learnt the King's doubt, officers frantically sent a reminder to Java, and reported back to the King that the Surakarta court would ship the gamelan to the Thai Consulate at Batavia who would, on December, subsequently send the instruments from a port in Semarang city. When the gamelan has arrived, Thai officials arbitrarily separated it into two sets, one sent to the National Museum, Phra Nakhon while the other stored at the Music Division, Fine Arts Department. Details regarding the separation of the gamelan shall be discussed later.

\section{DECULTURATION OF JAVANESE (SUNDANESE) ANGKLUNG TO THAI ANGKLUNG VIA MUSICAL GENETIC MODIFICATION}

The Sundanese angklung, known as angklung chawa (Javanese angklung) by most Thais, was first brought as a mere souvenir or gift from Java following HM. King Chulalongkorn's visit (Amatyakul 1985, 5). It was brought to the country for the second time, this time with musical purpose and along with musical ideas from Javanese gamelan, by Luang Praditpairoh who accompanied Prince Bhanurangsi Savangwongse to Java.

The angklung brought by Luang Praditpairoh in 1908 did not only refer to the instrument itself but also included repertory, and to either aspects changes were 
made in multiple ways to make the original Sundanese angklung more "Thai". Sonically, its pitch frequencies were retuned to match that of Thai music while its physical appearance was changed by adding another bamboo tube to two already-existing tubes. The original way of playing angklung - suspended on a player's write while being swing sideways by the other hand - was replaced by holding angklung on each hand and shaking it to-and-fro.

Musical concepts of Javanese gamelan was applied to and incorporated with that of Thai classical music through Luang Praditpairoh's interpretation in an attempt to balance the two musical genres with Thai angklung as mediator. Inspired by Javanese musical pieces, The Thai music master, using Thai classical music concept, wrote several new compositions. One of them was Yawa kao which was based on Bima Kurda (Hughes 1992, 17). Indigenous Javanese melodies were adapted for Thai angklung, for examples, karad raya and kadiri (Thubthimsri, personal comm). Together with other pieces, these newly composed pieces were played one after another, resulting in what is known as phleng chud homrong yawa or the Javanese Suite, which was known alternatively as tab busensog - the word busensog came from Buitenzorg city, today Bogor in the West Java - consisting of busensog, yawa mai, samarang, karad raya, kadiri, and bukantumo.

\section{PROCESS OF MUSICAL GENETIC MODIFICATION BY THAI MUSIC AGAINST JAVANESE (SUNDANESE) ANGKLUNG}

Step 1. The first generation of Sundanese angklung, represented by F0S, was cross-mixed with the Thai tuning system, represented by F0T, resulting in the second generation of Sundanese angklung with Thai tuning and appearance, represented by F1ST.
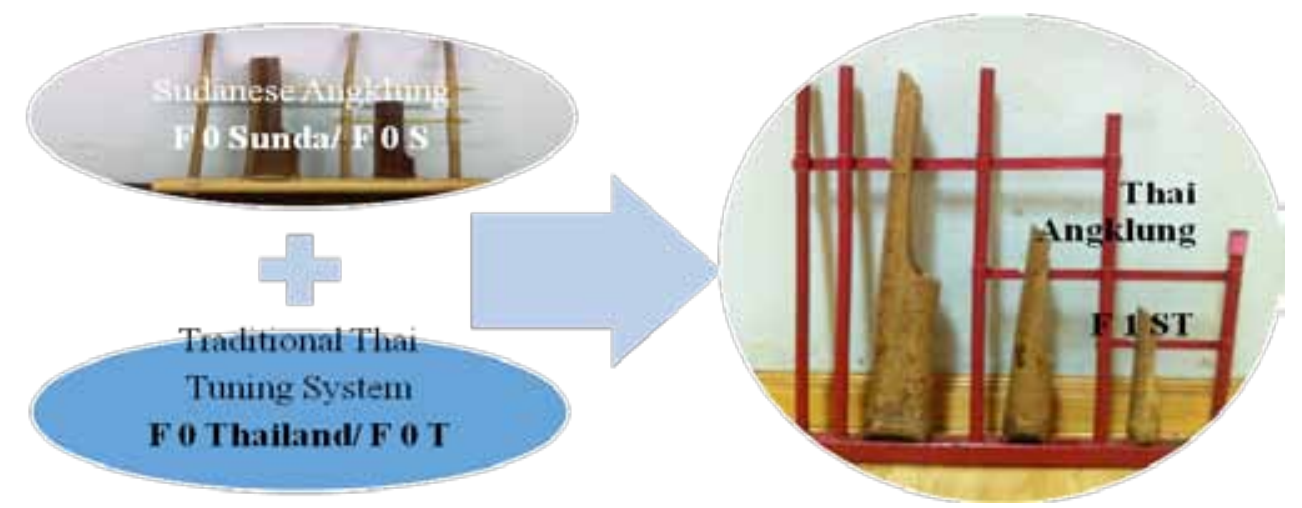

Step 2. The first generation of Javanese repertory, represented by F0J, was crossedmixed with Thai repertory, represented by F0T, resulting in the Javanization of Thai repertory or Javanese-accented Thai repertory, represented by F1JT 


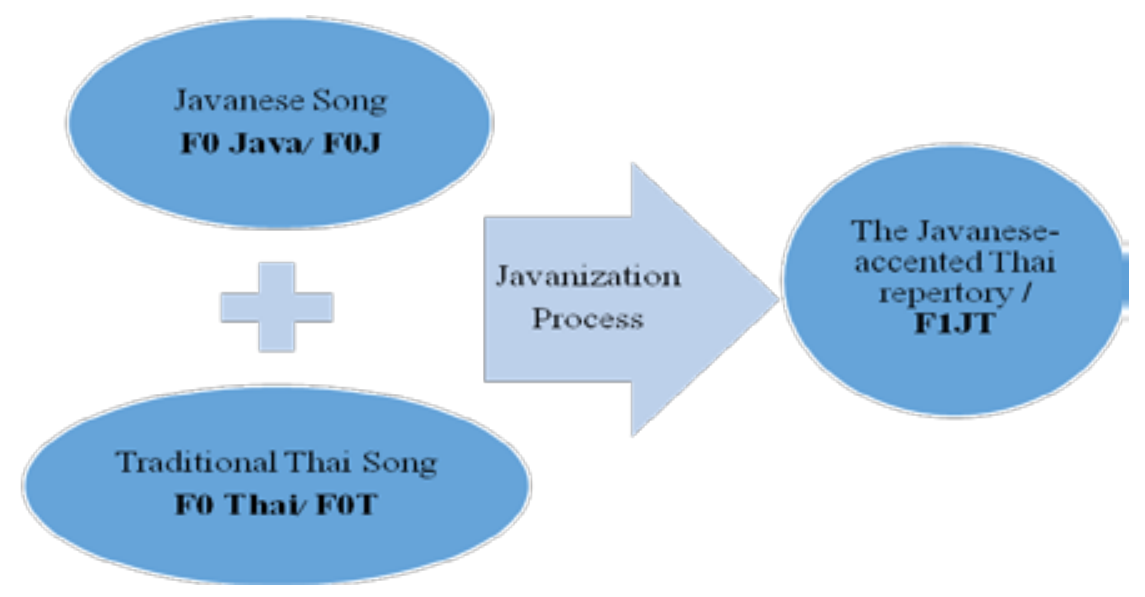

Step 3. The Javanese-accented Thai repertory (F1JT) was performed using Thai angklung (F1ST), resulting in a new form of music which is a fusion of Sundanese Music, Javanese Music and Thai Music in a ratio of 1:1:2, respectively. The resultant third generation of music is represented by F2SJ2T

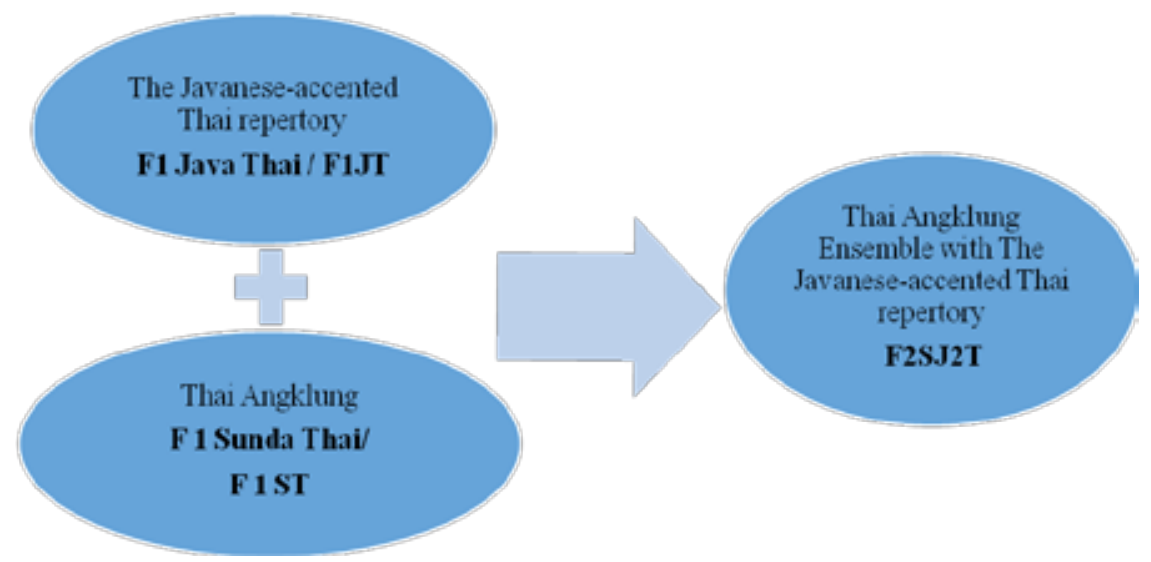

From the above process, it is found that Thai angklung bears more Thai characteristics than Javanese or Sundanese because of the ratio in which Thai music influence is twice as much as that of either Javanese or Sundanese music. Thus, changes made to Indonesian angklung whether in terms of tuning system, repertory, appearance, or performance practice disabled the instrument from retaining the characteristics of Indonesian angklung. Because of those changes, Thai angklung has since played the role of cultural connector between Thai and Indonesia through performed repertory. This can be regarded as one major accomplishment of Luang Praditpairoh who was instrumental in introducing and popularizing angklung as well as Javanese-accented Thai repertory or Pleng $B h a s a^{1}$. Today there are numerous angklung competition, teaching and learning

1 PLENG BHASA is Thai traditional repertoires that imitate idiomatic melody of various foreign nations. It has been present since the Ayuddhya Era. Earlier, the repertoire is called by the name of nation whose idiomatic melody is imitated therein, such as Nerapati, Patong (probably derived from Melayu word - Patung - which means a statue), Mudtrum (probably refers to MataramEmpire in Java, Indonesia). Later in the Rattanakorin Era, it is customary to begin the title of an accented repertoire with the name of respective imitated country, such as CHIN (China) KHIM LEK, KHMEN (Khmer) PAI RUEA, MON (Mon) RUM DAAB, PAMA (Burma) RUM KWAN. The repertoires of various accents are often played as a suite, known as "AWK PASA" or "AWK SIB SONG PASA" 
of angklung in almost every level of Thai schools. The pervasiveness of angklung has sometimes caused confusion over whether it is a Thai or a foreign instrument. Regarding this matter, government from the Philippines once sent, via Royal Thai Embassy of Manila, an official letter requesting donation of angklung as a tool to study Thai culture (National Archivesof Thailand 1968).

\section{MUSICAL DECULTURATION OF JAVANESE GAMELAN TO CO-EXIST WITH THAI MUSIC}

In 1929, a complete set of Javanese gamelan Surakarta Model, donated by Susuhunan (sultan) Pakubawana X (P.B. X) to H.M. King Prajadhipok, has arrived in Thailand following the latter's return to Thailand (National Archives of Thailand 1929). Being the first gamelan to have imported to Thailand, The set contained instruments of two tuning systems: pelog and slendro. Later on this gamelan was separated into two groups because the Thais understood to have received two different sets of Javanese musical instruments (Amatyakul, personal comm). One of them used to be displayed in the National Museum, Phra Nakhon, but is now being stored elsewhere, while the other was in the custody of the Music Division, Fine Arts Department who used it occasionally to accompany Inao and perform various Javanese-accented pieces composed by Thai music masters.

The division of one unitary set of Javanese gamelan into two smaller sets posed certain intriguing points worth studying. Originally, typical Javanese gamelan contains two tuning systems: the seven-pitch slendro and the five-pitch pelogwhose pitches are numbered 1, 2, 3, 4, 5, 6, 7 and 1, 2, 3, 5, 6, respectively. Due to great discrepancy, the two tuning systems cannot be played together. Except for pitch of the note number 6 or nem which is identical in both systems, pitches of all corresponding notes are tuned differently. The partition the gamelan done by the Thai government, however, neither conformed to the tuning system nor followed the Javanese ensemble formation, making the so-separated sets contain slendro as well as pelog system. Even if one divides instruments correctly based on two tuning configurations, the entire set of gamelan should not have been separated from the first place because there are instruments used in both tunings, i.e. kendang (drum), some kempul (suspended gongs), and gong.

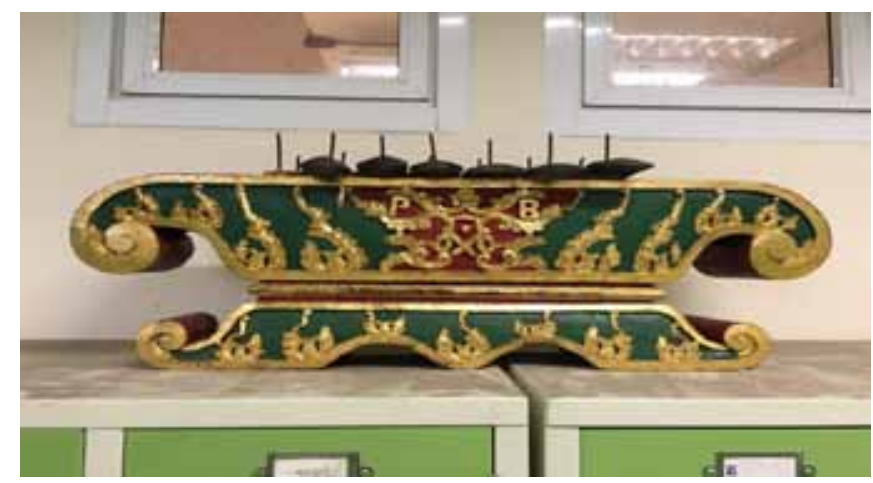

Saron at the Music Division Department of Fine Arts, Thailand Photo: Surasak Jamnongsarn, 12 April 2015 


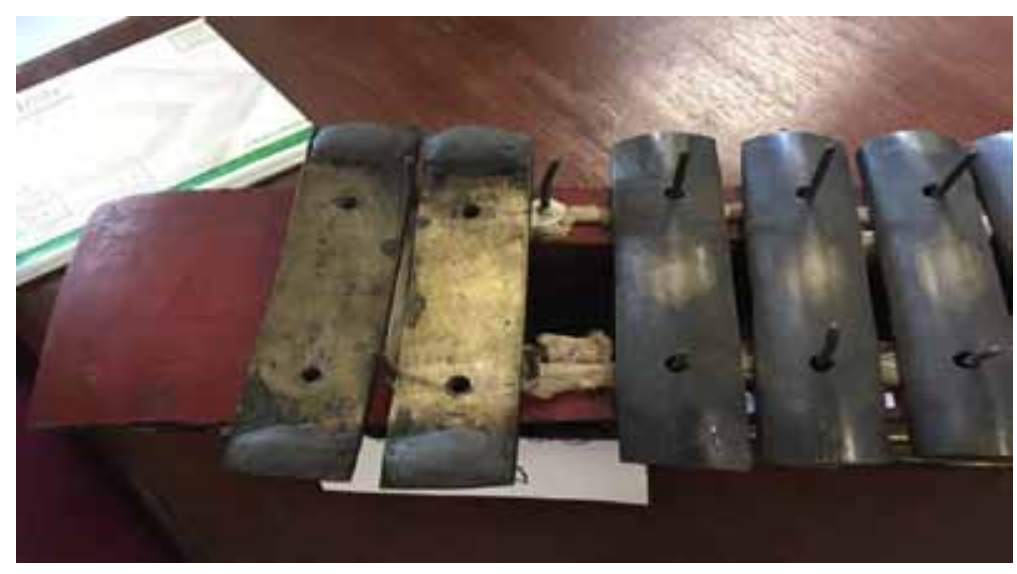

Retuned Saron

Photo: Surasak Jamnongsarn, 12 April 2015

Unlike the set of Javanese gamelan once displayed in the National Museum, Phra Nakhon, which was treated merely as exhibition items, the set of Javanese gamelan under the custody of the Music Division, Fine Arts Department is being taken care of by Thai music masters and is more in playable condition than the other. The set has been retuned to match tuning system of Thai music. This has enabled the instruments, as a representation of Java, to accompany Inao, a Thai court play, by playing Thai repertory along with piphat ensemble (Phachoen Kongchok 2015, personal comm).

\section{THE JAVANESE ACCENTED SONG IN THAI MUSICAL REPERTOIRE: A PROCESS OF WRITING WITH-NONE-JAVANESE INVOLVED}

Attempts to increase the scope of Thai traditional music are always happening. The same can be said in the case of Javanese-accented Thai traditional repertoires contributed by Luang Pradit Pairoh's (Sorn Silpabanleng). This is a very interesting rise in increasing musical scope not only for the sake of musical contexts alone, but also of association with other contexts such as international politics, Thailand's national history and the aspects of applying foreign music to establish the stability of court music. After the introduction of Indonesia's Angklung and Gamelan in Thailand, both instruments played key roles in propelling the emergence of new musical genre, i.e. Javanese-accented Thai traditional repertoires. Based on the already existing Language Suite combined with the fresh knowledge of Javanese music, whether in the form of Angklung, Javanese Gamelan, or the memorized songs from Indonesia, a new Javanese-accented composition for Thai Angklung was created under the title Home Rong Java (the Java overture suite). Since then, Home Rong Java has influentially inspired other Thai traditional music masters to compose subsequent Javanese-accented Thai traditional repertoires such as Khaek A Wang by Master Montri Tramote, a Javanese-accented variant version of Khaek Sai by Master Chaloem Buathang. Following highly-reputed Thai traditional musical masters' participation in composing Javanese-accented Thai traditional repertoires, there was an immense force that raised this particular genre of musical composition, 
concept and its overall popularity to a height that it became one of the prominent accented-repertoires among the vast list Thai traditional compositions. The composed Javanese-accented Thai traditional repertoires can be sorted into following groups-

1. Unmodified Indonesian original repertoires, e.g. Burung Kakatua.

2. Composed repertoires based on Javanese original repertoires, e.g. Yawa Kao being composed based on Bima Kurda.

3. Completely new Thai traditional repertoires with Javanese accent, e.g. Rabum Krailas Samroeng ${ }^{2}$, Rabum Srivijaya. ${ }^{3}$

4. A Javanese-accented variant version of an existing repertoire, e.g. Khaek Sai.

In this paper, the writer would like to give an example of the modification of an existing Thai traditional repertoire to produce a Javanese-accented variation by referring to Khaek Sai SONG CHAN which is composed by Luang Pradit Pairoh (Sorn Silpabanleng). The purpose for citing this popular repertoire is to give an idea of how musical javanization process was carried out by Luang Pradit Pairoh. Also, this is to indicate the area of Javanese culture according to the viewpoint of Thai traditional musicians that although it is a very well understood by all that Khaek Sai refers to the state Saiburi or Kedah, located North of present Malaysia, but still Thai traditional musicians do not seem to have any doubts towards the use Javanese-accented variation.

Khaek Sai Song (2nd Chan)
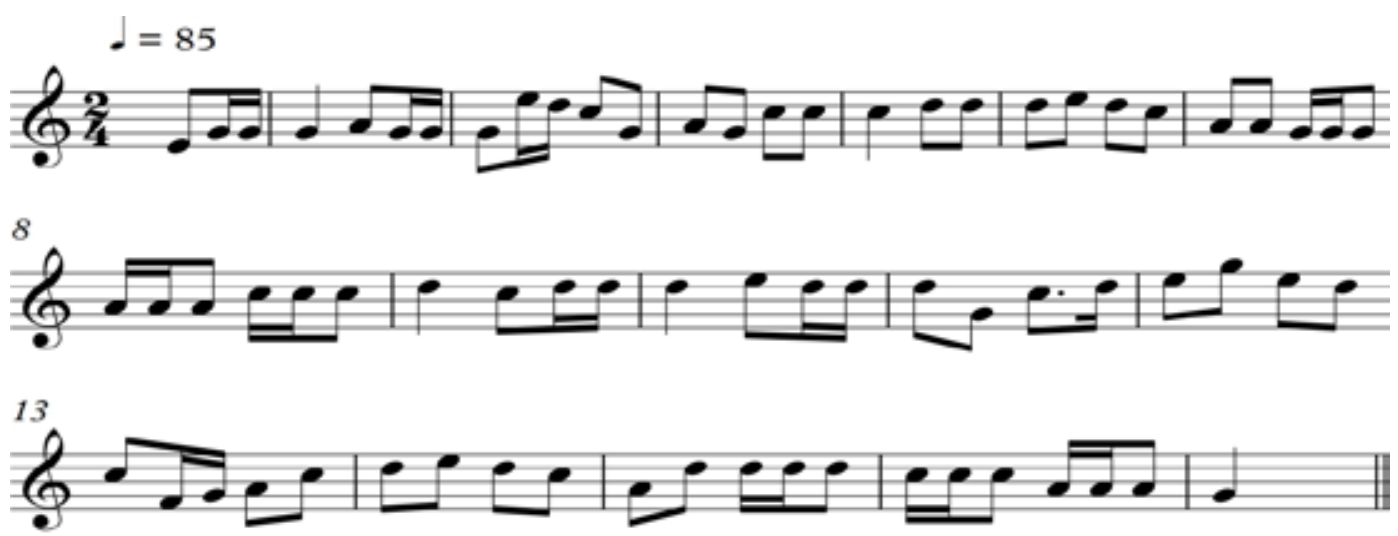

2 RabumKrailasSamroeng is a repertoire composed by Master MontriTramote to accompany KrailasSamroeng Dance. The dance is a part of Manohra theatrical play. Premiered in 1955, the repertoire is Javanese-accented and was also used as an interim repertoire for one of Archeological Dance series, RabumSrivijaya, whose particular repertoires was not yet complete.

3 Rabum Srivijaya is a repertoire composed by Master Montri Tramote for the Srivijaya dance in 1966. The repertoire was inspired from musical instruments carvings on Borobudur in Java Island. 
Khaek Sai Song in Javanese Accent
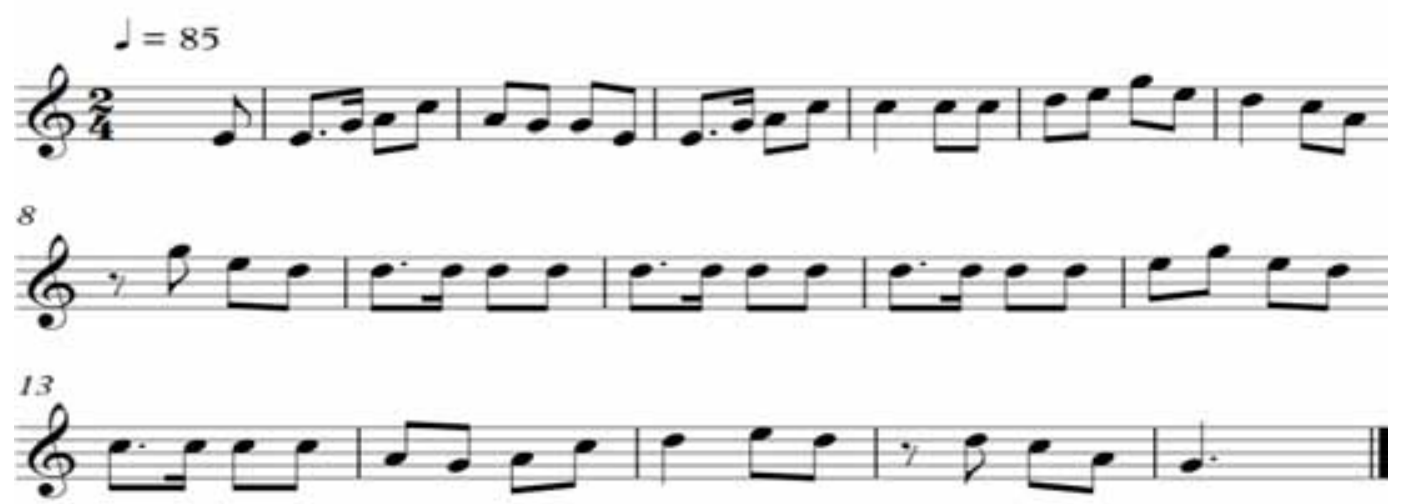

For a brief explanation, the original melody of the repertoire is modified, producing new melodic character, while conserving the repertoire's length. The term variant means changes to melodic progressions, but not to the important notes, to give different melodic and rhythmic effect than that of the original. The composer, here, has chosen to install Javanese accent as a new variant character. In order to achieve this, several streams of knowledge about theory of Thai traditional music is utilized. For example, composer must be able to synthesize special characters of Javanese music through perception of the melodic direction of various Javanese repertoires. If it is found to be in disjunct progression, the feature is then applied into his/her composition of Javanese-accented repertoires. Another example is that composer must analyze how tone colors/timbres of each Javanese musical instrument differ from one another. Once detected, the difference is then applied into the Javanese-accented Thai traditional repertoires in order to convey the musical expression qualities of the Java through the new composition. The level of these abilities, along with other necessary ones, depends on a composer's capability of synthesis through listening. The more proficient, the lesser times of listening required for synthesis. In addition, there is also use of suitable Javanese rhythmic instruments such as drums and its Nha Tap ${ }^{4}$ (rhythmic pattern) to emphasize more Javanese characteristics. Another interesting observation is the effort to balance the composition's Javanese authenticity with the delicacy of Thai traditional music by creating new lyrics of foreign language, which actually is the Melayu language rather than original Java language.

\section{REFERENCES}

Amatyakul, Poonpit. Angklung. 2528 B.E. Bangkok: Raksipp.

Cherdchoo, Waraporn. Kham Dontri Thai Chue Sai Jawa (Javanese word in Traditional Thai Music). 2553 B.E. Pitsanulok: Naresuan University.

4 Nha Tap is a rhythmic pattern of the drums that punctuates a musical piece. Its pattern can sometimes provide a clue to idiomatic features of a musical piece. For example, a Chinese drum is used to play Nha Tap in a Chineseaccented repertoire. 
Chulalongkorn, H.M. King. Raya Thang Thiew Jawa Kwa Song Deaun (the Journey to Java for more than two months). 2555 B.E. Bangkok: Saengdao.

Dhiravat na Pombejra. 2008. Javanese Horses for the Court of Ayutthaya. In Breeds of Empire: The "Invention" of the Horse in Southeast Asia and Southern Africa, 1500-1950. Nordic Institute of Asian Studies: Studies in Asian

Hughes, David W. 1992. Thai Music in Java, Javanese Music in Thailand:

Two Case Studies, British Journal of Ethnomusicology Volume 1, Issue 1: London.

Pachoen Kongchoke (Kru Chean). 73 years, senior traditional Thai musician, Department of Fine Arts, Sriprawat Nonthaburi Thailand. Bangkok.

Pirasit Buatang (Kru Pat). 70 years, senior traditional Thai musician, Department of Fine Arts, Bangyai Nonthaburi Thailand.

Pradjapangrawit, R. Ng. 1990. Serat Sujjarah Utawi Riwating Gamelan Wedhapradangga (Serat Saking Gotek). Surakarta: STSI Surakarta dan Ford Foundation.

Ricklefs, M. C. 2001. A History of Modern Indonesia since c.1200. Houndmills: Palgrave.

Satien Duangchanthip. 50 years, Traditional Thai music historian, Wat Paknam Tai, Thonburi, Bangkok.

Sawit Thabthimsri. 70 years, Traditional Thai music expert. Bangyai Nonthaburi.

Soedarsono, R.M. dan Tati Narawati. 2011. Dramatari di Indonesia, Kontinuitas dan Perubahan. Yogyakarta: Gadjah Mada University Press.

Suharto, Imtip Pattajoti. 2012. The Journey to Java by a Siamese King. Bandung: ITB Press.

Sumarsam. 2003. Gamelan: Interaksi Budaya dan Perkembangan Musikal di Jawa. Yogyakarta: Pustaka Pelajar.

\section{National Archives of Thailand, Bangkok.}

B.E. 2451 สมเด็จเจ้าฟ้ากรมพระภาณุพันธุวงษวรเดชเสดจชวา (the Journey to Java by H.R.H. Bhanurangsi).ตอน 2 หมวดเบ็ดเตล็ด แฟ้มที่ 56.

B.E. 2472

การส่งเครื่องปี่พาทย์และเครื่องละครซึ่งซูซูููนันและมังโกโนโกโรทูลเกล้า

(Transport of Gamelan ensemble and theatrical costumes, presented by Susuhunan and Mangkunegoro).เลขที่ 12 .

B.E. 2511 ขอบริจาคเครื่องดนตรีอังกะลุง (Donation request for Angklung set by University of the Philippines).แผนก ต.ท.10. กระทรวงการต่างประเทศ ๗. 